\title{
Efektivitas Tanaman Lemna (Lemna perpusilla Torr) Sebagai Agen Fitoremediasi Pada Keramba Jaring Apung (KJA) Disekitar Tanjungmas Semarang
}

\author{
Umarudin, Jumriah Nur, Ayu Wulandari dan Munifatul Izzati \\ * Magister Biologi Universitas Diponegoro \\ Jurusan Biologi Universitas Diponegoro \\ Jl. Prof. Soedarto, SH, Kampus Tembalang, Semarang 50275
}

\begin{abstract}
The port of Tanjung Emas, Semarang as the main port in Central Java that have activity increases pollution impact. Hence the need for special attention and handling by using aquatic plants Lemna perpusilla. The purpose of this research is to know the physical condition of floating around the net keramba Tanjungmas city of Semarang. Designing the application fitoremediasi on floating around the net keramba Tanjungmas city of Semarang and Knowing the prospects of development of fitoremidiasi. This paper uses a case study research methods (case study), which this method has the goal to provide a detailed description of the background, traits and characters typical of cases of water are there in KJA around the Tanjugmas City of Semarang by taking the research object. While this research is the observation and interview is open ended. So that the data obtained indicate that the physical condition of floating around the net keramba Tanjungmas Semarang blackened water greenish colours, smells, and oily. Application design fitoremidiasi by Lemna perpusilla utilize water plants and fish seed banding continued with the observed results. As well as direct application on the KJA in the waters of Tanjung Mas with lemna and seed density setting fish whitefish. Fitoremidiasi development prospects by looking at opportunities to fish bandeng and Lemna perpusilla.
\end{abstract}

Key words: Fitoremediasi, KJA, Fish Bandeng, Lemna perpusilla, Pollution.

\begin{abstract}
Abstrak
Pelabuhan Tanjung Emas Semarang sebagai pelabuhan utama di Jawa Tengah yang memiliki aktivitas semakin meningkat yang berdampak pencemaran. Oleh karena itu perlu adanya perhatian dan penanganan khusus dengan memanfaatkan tumbuhan air Lemna perpusilla. Tujuan dari penelitian ini adalah untuk mengetahui kondisi fisik keramba jaring apung disekitar Tanjungmas Kota Semarang. Mendesain aplikasi fitoremediasi pada keramba jaring apung disekitar Tanjungmas Kota Semarang dan Mengetahui prospek pengembangan fitoremidiasi. Karya tulis ini digunakan metode penelitian studi kasus (case study), yang mana metode ini mempunyai tujuan untuk memberikan gambaran secara mendetail tentang latar belakang, sifat-sifat serta karakter-karakter yang khas dari kasus air yang ada di KJA sekitar Tanjugmas Kota Semarang dengan mengambil objek penelitian air tersebut. Sedangkan penelitian ini bersifat observasi dan wawancara secara open ended. Sehingga diperoleh data yang menunjukkan bahwa kondisi fisik keramba jaring apung disekitar Tanjungmas Kota Semarang yaitu warna air menghitam kehijauan, berbau, dan berminyak. Desain aplikasi fitoremidiasi yaitu dengan memanfaatkan tanaman air Lemna perpusilla dan benih ikan bandeng dilanjutkan dengan mengamati hasilnya. Serta aplikasi langsung pada KJA di Perairan Tanjung Mas dengan pengaturan kepadatan lemna dan benih ikan bandeng. Prospek pengembangan fitoremidiasi dengan melihat peluang ikan bandeng dan Lemna perpusilla.
\end{abstract}

Kata kunci : Fitoremediasi, KJA, Ikan bandeng, Lemna perpusilla, Pencemaran.

\section{PENDAHULUAN}

Pelabuhan Tanjung Emas Semarang sebagai pelabuhan utama di Jawa Tengah yang memiliki peranan penting bagi perekonomian sehingga tuntutan akan jasa pelabuhan semakin meningkat terus. Peningkatan permintaan akan jasa pelabuhan mendorong aktivitas di pelabuhan semakin tinggi. Selain sebagai sarana transportasi juga sebagai 
sarana perdagangan dan bisnis, industri, rekreasi, cagar budaya serta permukiman. Laporan dari Bapeda menunjukkan bahwa terdapat beberapa masalah lingkungan yang terjadi di sekitar kawasan Pelabuhan, hal ini karena aktivitas pelabuhan yang semakin meningkat seperti kegiatan kapal-kapal yang berlabuh di pelabuhan menghasilkan banyak limbah baik berupa buangan minyak, selain itu juga aktivitas industri dalam proses produksinya juga menghasilkan buangan baik cair maupun gas yang dapat menyebabkan pencemaran di sekitar kawasan pelabuhan. Aktivitas darat lainnya berupa pergudangan, docking atau perbaikan kapal, perkantoran, dan industry kayu yang menghasilkan limbah kulit kayu yang dibuang ketempat KJA, serta di dekat tempat tesebut adanya tempat pembuangan sampah yang menyebabkan dampak pencemaran.

Dampak pencemaran air pada daerah Budidaya Keramba Jaring Apung (KJA) yang berada di daerah sekitar Pelabuhan Tanjungmas Semarang dengan kondisi awal pencemaran warna air menghitam kehijauan, berbau, dan berminyak. Oleh karena itu perlu adanya perhatian dan penanganan khusus. Salah satu solusi yang ditawarkan dengan memanfaatkan tumbuhan air lemna atau mata lele untuk menanggulangi jumlah pencemar dengan cara menyerap, mengumpulkan dan mendegradasi bahan-bahan pencemar tertentu yang terdapat dalam keramba jaring apung yang kita kenal dengan phytoremediasi. Fitoremediasi adalah teknologi pembersihan zat polutan dari badan air yang telah tercemar dengan menggunakan tanaman. Teknologi ini mudah, dan murah, serta memberikan efek negative yang kecil bagi kesehatan (Khiatuddin. 2003 dalam Kusumastuti. 2009).

Lemna atau 'mata lele' (Lemna perpusilla Torr) merupakan tumbuhan akuatik kecil yang hidup mengapung bebas di perairan air tawar dan merupakan satu dari 13 jenis marga Lemna yang termasuk dalam suku Lemnaceae (Pancho \& Soerjani, 1978; Landesman et al., 2005; Hasan \& Chakrabarti, 2009). Jenis tumbuhan ini hidup kosmopolitan di daerah tropis, terutama di perairan tergenang di daerah dengan ketinggian rendah hingga sedang. Selain itu juga tanaman ini adalah jenis tanaman mengapung (floating). Jenis tanaman ini dapat digunakan untuk pengolahan limbah karena tingkat pertumbuhannya tinggi dan mampu untuk menyerap hara langsung.

Berbagai jenis lemna telah dimanfaatkan dalam proses pengolahan limbah domestik dan industri di beberapa Negara. Cedergreen \& Madsen (2002) melaporkan kemampuan Lemna minor mampu menyerap $\mathrm{NH}_{4}$ dan $\mathrm{NO}_{3}$ melalui bagian akar dan daunnya. Pada percobaan in vitro, laju penyerapan senyawa nitrogen dan fosfor pada tumbuhan ini mencapai $3,36 \mathrm{~g} / \mathrm{m} 2 / \mathrm{hari}$ dan $0,20 \mathrm{~g} /$ $\mathrm{m} 2 /$ hari, sementara di lapangan mencapai $2,11 \mathrm{~g} /$ $\mathrm{m} 2 /$ hari dan 0,59 g/ m2/hari (Cheng et al., 2002). El-Kheir et al. (2007) melaporkan kemampuan Lemna gibba menyisihkan berbagai parameter, meliputi padatan tersuspensi, $\mathrm{BOD}, \mathrm{COD}, \mathrm{NO}_{3}$, $\mathrm{NH}_{4}, \mathrm{O}-\mathrm{PO}_{4}, \mathrm{Cu}, \mathrm{Pb}, \mathrm{Zn}$, dan Cd berturut-turut sebesar 96,3\%, 90,6\%,89,0\%, 100\%, 82,0\%, $64,4 \%, 100 \%, 93,6 \%$, dan $66,7 \%$.

Disamping sebagai agen pengolah limbah, jenis-jenis lemna juga diketahui memiliki potensi besar sebagai pakan (Hasan \& Chakrabarti, 2009). Pada kondisi optimal jenis tumbuhan ini dapat menggandakan biomassanya hanya dalam waktu 2 hari (Landesman, 2005), sehingga pada pola tanam yang efektif dapat mencapai produktivitas $13-38$ ton berat kering/Ha/tahun (Ansal et al., 2010). Jenis-jenis lemna juga mempunyai kandungan protein tinggi, yaitu mencapai $10-43 \%$ berat keringnya (Leng et al., 1995; Landesman, 2005), sehingga nilai produktivitas protein kultur lemna dapat mencapai 6-0 kali lebih tinggi dibandingkan dengan luasan tanaman kacang kedelai (Landesman et al., 2005). Beberapa penelitian telah dilakukan untuk memanfaatkan jenis tumbuhan untuk pakan berbagai jenis hewan, yaitu itik, babi dan ikan nila (Leng et al., 1995). Uji coba di Brasil memperlihatkan potensi biomassa kering lemna untuk suplemen pakan ikan nila hingga mencapai 50\% tanpa mengganggu kinerja tumbuhnya (Tavares et al., 2008). Rasio konversi pakan (FCR; Food Conversion Ratio) biomassa Lemna gibba untuk pakan ikan nila adalah 1,5; sementara laju tumbuh spesifik ikannya dapat mencapai 0,71 (El-Shafaia et al., 2004).Tanaman ini mempunyai potensi untuk menyerap logam berat dari air, sehingga 
kemungkinan dapat digunakan untuk pengolahan limbah yang mengandung logam berat sangat besar. Berdasarkan informasi-informasi di atas, maka dipandang perlu untuk mengkaji efektivitas tumbuhan lemna yang tumbuh tersebar di Indonesia untuk dijadikan sebagai agen fitoremediasi pada keramba jaring apung (KJA) di sekitar Tanjungmas Kota Semarang.

Tujuan dari karya tulis ini adalah untuk mengetahui kondisi fisik keramba jaring apung disekitar Tanjungmas Kota Semarang. Mendesain aplikasi fitoremediasi pada keramba jaring apung disekitar Tanjungmas Kota Semarang dan Mengetahui prospek pengembangan fitoremidiasi.

\section{BAHAN DAN METODE}

Karya tulis ini digunakan metode penelitian studi kasus (case study), yang mana metode ini mempunyai tujuan untuk memberikan gambaran secara mendetail tentang latar belakang, sifat-sifat serta karakter-karakter yang khas dari kasus air yang ada di KJA sekitar Tanjugmas Kota Semarang dengan mengambil objek penelitian air tersebut. Sedangkan penelitian ini bersifat observasi dan wawancara secara open ended. Penelitian ini dilakukan terhadap air di KJA sekitar Tanjungmas Kota Semarang. Penelitian ini digunakan untuk mengetahui kondisi fisik keramba jaring apung disekitar Tanjungmas Kota Semarang. Mendesain aplikasi fitoremediasi pada keramba jaring apung disekitar Tanjungmas Kota Semarang dan Mengetahui prospek pengembangan fitoremidiasi.

\section{HASIL DAN PEMBAHASAN \\ Kondisi Fisik Karamba Jaring Apung Sekitar Tanjung Mas}

Pencemaran perairan ini pada akhirnya berdampak pada pencemaran air daerah Budidaya Keramba Jaring Apung (KJA). Indikasi awal pencemaran di KJA adalah warna air menghitam kehijauan, berbau, dan berminyak. Berikut ini salah satu area budidaya ikan bandeng dengan sistem KJA yang menjadi lokasi survey peneliti lakukan dengan tanda-tanda ketercemaranya yang tersaji pada Gambar I dibawah ini.
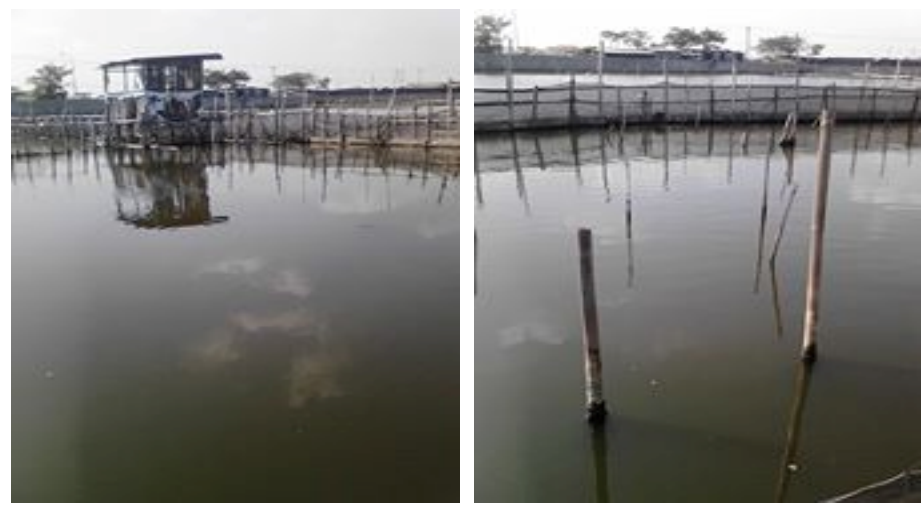

Gambar 1. Kondisi Area Tambak Sekitaran Tanjung Mas

Budidaya ikan bandeng ini ternyata tidak hanya berkembang di air payau, namun berkembang di air tawar maupun laut dengan sistem Keramba Jaring Apung (KJA). Keramba jaring apung atau kantong jaring terapung adalah berupa kantong jaring yang letaknya terapung dipermukaan air dengan disengaja oleh pengapung yaitu berupa drum (Rochdianto, 2004) Permasalahan limbah dari industri dan domestik, bukan menjadi hal satu-satunya yang menyebabkan ketercemaran dan masalah pada budidaya ikan KJA karena sistem budidaya ikan sistem KJA juga intensif menghasilkan limbah (kotoran ikan dan sisa pakan yang tidak termakan) yang nantinya akan merangsang produktivitas perairan dan mempengaruhi karakteristik biotik dan abiotik perairan (Krismono, 1992). Pemberian pakan yang dilakukan secara adbilitum (terus menerus hingga ikan betul-betul kenyang) menyebabkan banyak pakan yang terbuang dan terakumulasi di dasar perairan sehingga dapat menyebabkan turunnya kadar $\mathrm{O}_{2}$ dan meningkatkan kadar $\mathrm{NH}_{3}, \mathrm{NO}_{2}$ dan $\mathrm{H}_{2} \mathrm{~S}$ yang pada konsentrasi tertentu dapat mematikan ikan (Sukadi, 1991). Menurut Juaningsih (1997), sisa pakan dan buangan padat ikan akan terurai melalui proses dekomposisi membentuk senyawa organik dan anorganik, beberapa diantaranya senyawa nitrogen $\left(\mathrm{NH}_{3}, \mathrm{NO}_{2}, \mathrm{NO}_{3}\right)$ dan fosfor $\left(\mathrm{PO}_{4}\right)$. Kotoran ikan dapat menimbulkan deposisi yang meningkat di dasar perairan, selanjutnya mengakibatkan penurunan kadar oksigen di bagian dasar. 
Adanya kasus ini memungkinkan terjadinya proses penyuburan atau eutrofikasi di perairan yang berdampak pada kematian ikan, penurunan pertumbuhan ikan bandeng tak sempurna dan penurunan jumlah produktivitas ikan bandeng. Hasil tangkapan ikan bandeng di sekitar KJA ukuran bandenya relatif kecil dan jauh dari normal. Apalagi banyak yang mati, namun ketika hidup ukurannya kecil Berat ikan dewasa hanya separuh atau sepertiga dari normal (Kompas, 2010). Hal tersebut juga diungkapkan oleh salah satu warga yang sedang memancing pada area KJA tempat observasi peneliti, hasil wawancara kepada pemancing menyatakan bahwa terjadi penurunan pertumbuhan ikan dan penurunan hasil produksi serta terjadi pengurangan jumlah spesies ikan. Hal yang mendukung terjadinya penurunan produksi ini, yaitu 1) Menurunya daya dukung lahan (Carriying Capasity) secara terus menerus, 2) Terjadinya pencemaran lahan tambak dan air laut yang cukup tinggi.

Buangan limbah air budidaya selama operasional. yang mengandung konsentrasi tinggi dari limbah organik dan nutrien sebagai konsekuensi dari masukan bahan-bahan yang ditambahkan dalam budidaya udang/bandeng yang menghasilkan sisa pakan dan feces yang terlarut dalam air untuk kemudian dibuang ke perairan sekitarnya. Limbah-limbah pabrik yang bermuara ke laut. disini yang perlu dikritisi adalah dengan semakin banyaknya areal industri yang dekat dengan laut, maka akan semakin besar resiko dan pengaruh limbah yang yang terbuang untuk mencemari lahan-lahan dan perairan laut. Meskipun sudah ada kriteria AMDAL bagi industri-industri tersebut, tetapi jika tidak diimbangi dengan adanya pemetaan prioritas lahan lokasi industri, dan pengawasan secara kontinyu untuk mengukur kualitas limbah buanganya, maka secara akumulasi kedepan akan semakin memperbanyak permasalahan di ekosistem pertambakan.

Adanya penggunaan bahan-bahan kimia sebagai desinfektan (sterilisasi) air tambak dan untuk tujuan lain (contoh.membunuh pemakaian ikan dan plankton) Sebagian besar industri-industri tambak di negara kita ini masih banyak menggantungkan keberhasilan dalam berbudidaya tambak dengan menggunakan bahan-bahan kimia sebagai alat untuk sterilisasi air, membunuh kepiting, udang liar, ikan, ataupun plankton yang berlebihan. Memang untuk tujuan jangka pendek guna mengejar produksi sesaat, cara-cara ini sangat membantu, Tetapi dalam jangka panjang kedepanya, kita semua sering tidak menyadari bahwa cara-cara ini sangatlah berbahaya. Efek yang ditimbulkanya jauh lebih berbahaya jika dibandingkan dengan tujuan jangka pendek tersebut, karena jika kondisi lahan-lahan kita sudah rusak, perlu energi, waktu, dan dana yang cukup besar untuk merehabilitasi lagi diantaranya : 1) Iklim yang tidak menentu. 2) Dukungan tehnologi dan budaya masyarakat yang kurang perhatian akan lingkungan. 3) Padat Benur / benih yang terlalu tinggi. 4) Kualitas benur yang jelek.

\section{Desain Aplikasi Fitoremediasi}

Fitoremediasi adalah pemanfaatan tumbuhan sebagai agen peremediasi. Salah satu tumbuhan yang dapat mengintegrasikan upaya penanggulangan masalah kesuburan dan tercemar logam adalah Lemna perpusilla. Masalah kesuburan dan ketercemaran logam dianggap paling penting, hal ini dikarenakan mampu menyebabkan kurang optimumnya pertumbuhan ikan bandeng di area KJA, pengurangan jenis ikan bandeng, penurunan jumlah produksi ikan bahkan sampai pada kematian massal ikan akibat Upwelling.

Lemna atau 'mata lele' (Lemna perpusilla Torr) merupakan tumbuhan akuatik kecil yang hidup mengapung bebas di perairan air tawar. Jenis tumbuhan ini hidup kosmopolitan di daerah tropis, terutama di perairan tergenang di daerah dengan ketinggian rendah hingga sedang. Berikut gambar dari Lemna perpusilla yang tersaji pada Gambar 2. 

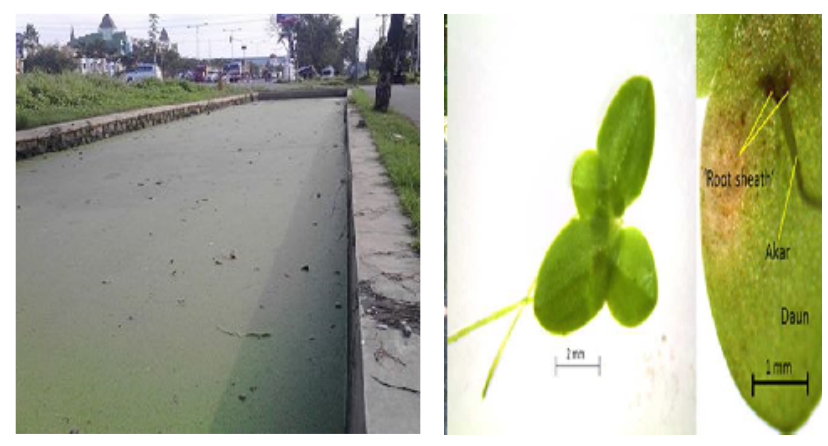

Gambar 2. Mata lele atau lemna (Lemna perpusilla Torr), populasi padat kultur dan insert individu tanaman.

Berbagai jenis lemna telah dimanfaatkan dalam proses pengolahan limbah domestik dan industri di beberapa negara, seperti Jerman, Amerika Serikat, Mesir, India, Bangladesh dan Israel (Cheng et al., 2002; El-Kheir et al., 2007; Ansal et al., 2010; Ferdoushi et al., 2008; Schröder et al., 2007). Cedergreen \& Madsen (2002) melaporkan kemampuan Lemna minor mampu menyerap $\mathrm{NH}_{4}$ dan $\mathrm{NO}_{3}$ melalui bagian akar dan daunnya. Alaert et al., (1996) melaporkan bahwa lemna menyisihkan 74\% TKN (Total Kjeldahl $N$ ) dan $77 \%$ TP (total Fosfor) di kolam pengolah limbah dengan waktu retensi 21 hari sehingga dapat dihasilkan luaran air dengan kandungan nutrient relative rendah, yaitu $2,7 \mathrm{mg} / \mathrm{L}$ TKN dan $0,4 \mathrm{mg} / \mathrm{L}$ TP. Adanya kemampuan dari beberapa jenis lemna dalam menanggulangi masalah tersebut membuat peneliti menggunakan jenis lemna perpusilla dengan pandangan memiliki kemampuan yang sama dengan lemna minor dan lemna giba. Berikut ini gambar mekanisme penyerapan kontaminan oleh lemana yang tersaji pada Gambar dibawah ini.
A
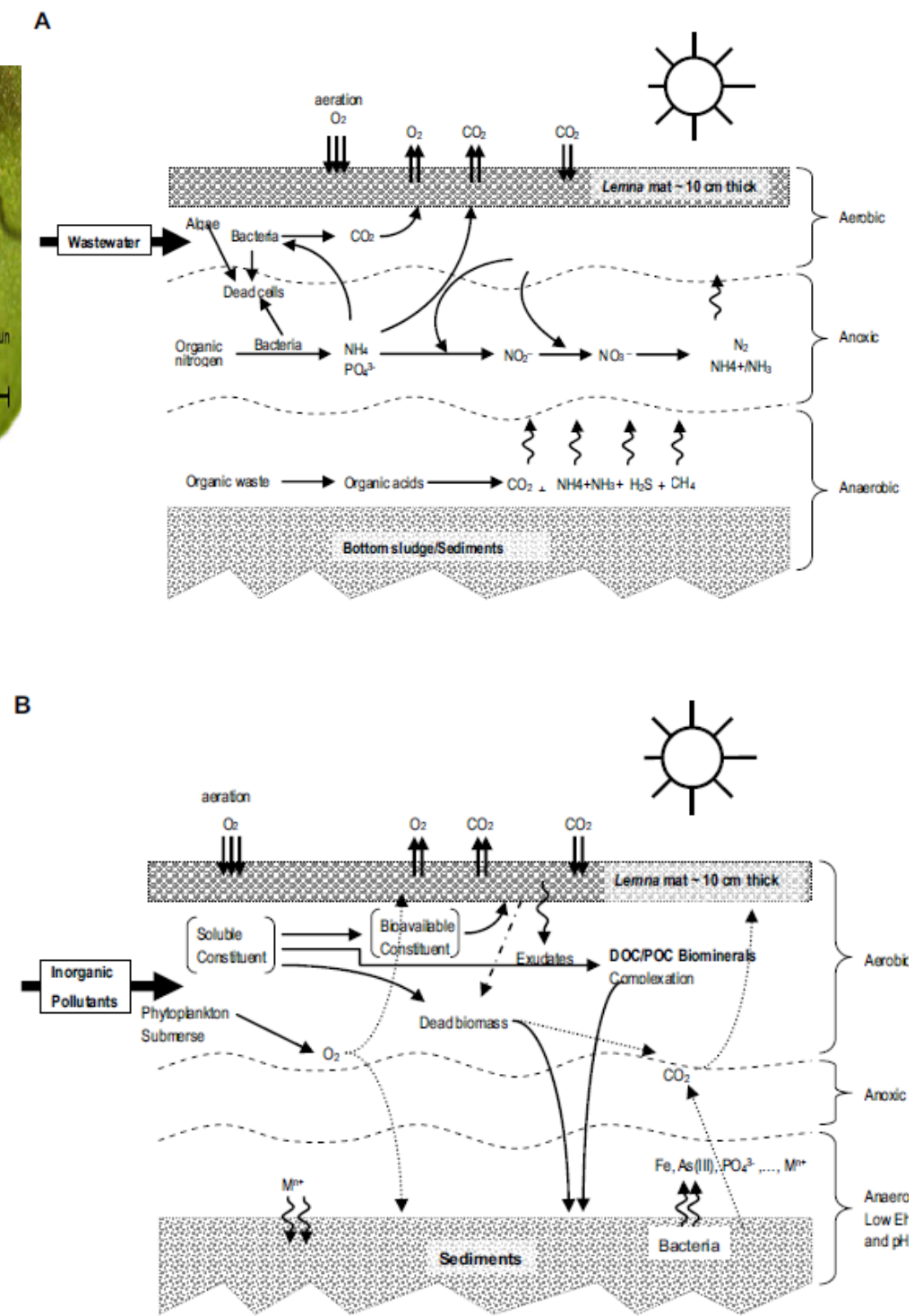

Gambar 3. Mekanisme Lemna terhadap penyerapan kontaminan

Mekanisme toleransi untuk pencemar organik dan anorganik dalam sel Lemna. Detoksifikasi yang terlibat dalam penyerapan aktif terjadi di bagian-bagian yang dapat melakukan proses detoks. Chelator (agen kelatin) yang terlibat adalah :Glutathionin (GSH), glukosa, Metallothionin (MT), nicotiamines (NA), asam organik dan ploychelatin. Berikut ini gambar mekanismenya yang tersaji dibawah ini. 


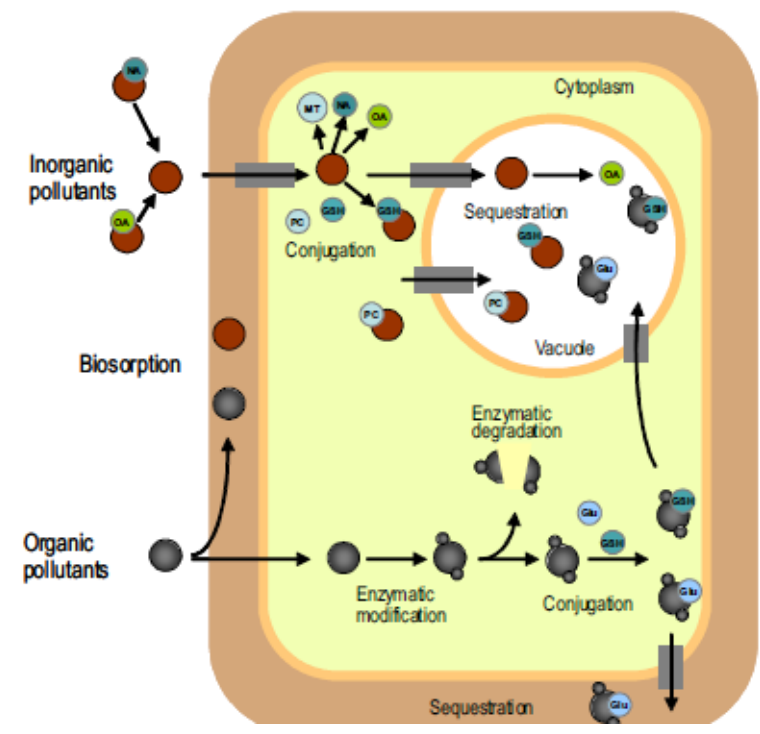

Gambar 4. Mekanisme toleransi pencemar didalam sel Lemna

Selanjutnya untuk desain aplikasi lemna perpusilla sebagai agen fitoremediasi pada keramba jaring apung disekitar Tanjungmas di Kota Semarang yang tersaji di Lampiran 1.

\section{Prospek Pengembangan}

\section{Peluang Pasar Ikan Bandeng}

Ikan Bandeng memiliki nilai ekonomi tinggi, hal ini dikarenakan pemanfaatannya yang begitu besar di Kota Semarang. Ikan bandeng tersebut sebagai bahan untuk membuat bandeng presto. Pasar komoditas bandeng tersebut dibutuhkan dalam beberapa tipe dan ukuran sesuai dengan tujuan pemanfaatannya. Kebutuhan ikan bandeng biasanya dijumpai pada rumah-rumah makan sea food, hotel, pasar swalayan dan pasar tradisional khususnya di Kota Semarang diperkirakan mencapai 6 ton per hari, dan saat ini baru terpenuhi $25 \%$ karena permasalahan pencemaran perairan. Selanjutnya bahwa problem utama yang dihadapi adalah kontinyuitas produksi, konsistensi mutu, utamanya dalam hal bobot, rasa, ukuran, penampilan fisik, dengan adanya alternatif pemecahan masalah ketercemaran diharapkan pemenuhan konsumsi ikan bandeng dapat tercukupi.

\section{Peluang Lemna perpusilta}

Disamping sebagai agen pengolah limbah, jenis-jenis lemna juga diketahui memiliki potensi besar sebagai pakan (Hasan \& Chakrabarti, 2009). Pada kondisi optimal jenis tumbuhan ini dapat menggandakan biomassanya hanya dalam waktu 2 hari (Landesman, 2005), sehingga pada pola tanam yang efektif dapat mencapai produktivitas 13-38 ton berat kering/Ha/tahun (Ansal et al., 2010). Jenis-jenis lemna juga mempunyai kandungan protein tinggi, yaitu mencapai $10-43 \%$ berat keringnya (Leng et al., 1995; Landesman, 2005), sehingga nilai produktivitas protein kultur lemna dapat mencapai 6-10 kali lebih tinggi dibandingkan dengan luasan tanaman kacang kedelai (Landesman et al., 2005). Beberapa penelitian pendahulu telah dilakukan untuk memanfaatkan jenis tumbuhan sebagai pakan berbagai jenis hewan, yaitu itik, babi dan ikan nila (Leng et al., 1995). Uji coba di Brasil memperlihatkan potensi biomassa kering lemna untuk suplemen pakan ikan nila hingga mencapai 50\% tanpa mengganggu kinerja tumbuhnya (Tavares et al., 2008). Rasio konversi pakan (FCR; Food Conversion Ratio) biomassa Lemna gibba untuk pakan ikan nila adalah 1,5; sementara laju tumbuh spesifik ikannya dapat mencapai 0,71 (ElShafaia et al., 2004). Berdasarkan data tersebut diharapkan Lemna perpusilla mampu meremediasi unsur hara dan dijadikan pakan baik itu untuk ikan bandeng, ikan mas, ikan nila, ikan gurame dan ikan bawal maupun jenis hewan yang lain sehingga nilai ekonominya besifat ganda dengan mengoptimalkan lahan dimana mampu menghasilkan ikan dengan produktivitas yang meningkat dan mampu memanen Lemna perpusilla utuk dijadikan bahan pakan yang pada akhirnya dapat pula memecahkan masalah lingkungan perairan yang tercemar.

\section{KESIMPULAN DAN SARAN \\ Kesimpulan}

Kondisi fisik keramba jaring apung disekitar Tanjungmas Kota Semarang yaitu warna air menghitam kehijauan, berbau, dan berminyak. Desain aplikasi fitoremidiasi yaitu dengan memanfaatkan tanaman air Lemna perpusilla dan benih ikan bandeng dilanjutkan dengan mengamati hasilnya. Serta aplikasi langsung pada KJA di 
Perairan Tanjung Mas dengan pengaturan kepadatan lemna dan benih ikan bandeng. Prospek pengembangan fitoremidiasi dengan melihat peluang ikan bandeng dan Lemna perpusilla.

\section{Saran}

Dari hasil penelitian yang telah dilaksanakan, maka dapat diajukan saran adalah perlu dilakukan penelitian lebih lanjut pemanfaatan tanaman air Lemna perpusilla atau jenis lemna lain ditempat di KJA di tanjungmas kota Semarang.

\section{DAFTAR PUSTAKA}

Ansal, M.D.; A. Dhawan \& V.I. Kaur. 2010. Duckweed based bio-remediation of village ponds: An ecologically and economically viable integrated approach for rural development through aquaculture. Livestock Research for Rural Development 22(7): Article \#129. Retrieved April 1, 2012, from http://www.lrrd.org/ lrrd22/7/ansa22129.htm.

Cheng, J.; L. Landesman; B. A. Bergmann; J. J. Classen; J. W. Howard \& Y. T. Yamamoto. 2002. Nutrient removal from swine lagoon liquid by Lemna minor 8627. Transaction of the ASAE, 45(4): 1003-1010. Cedergreen, N. \& T. V. Madsen. 2002. Nitrogen uptake by the floating macrophyte Lemna minor. New Phytologist, 155: 285-292.

El-Kheir, W.A.; G. Ismail; F.A. El-Nour; T. Tawfik \& D. Hammad. 2007. Assessment of the efficiency of duckweed (Lemna gibba) in wastewater treatment. International Journal of Agriculture and Biology, 9(5): 681-687.

El-Shafaia, S.A.; F.A. El-Goharya; F.A. Nasra; N. P. van der Steenb \& H.J. Gijzenb. 2004. Chronic ammonia toxicity to duckweed-fed tilapia (Oreochromis niloticus). Aquaculture, 232: 117-127.

Ferdoushi, Z.; F. Haque; S. Khan \& M. Haque. 2008. The effects of two aquatic floating macrophytes (Lemna and Azolla) as biofilters of nitrogen and phosphate in fish ponds, Turkish Journal of Fisheries and Aquatic Sciences, 8: 253-258.
Hasan, M.R. \& R. Chakrarbarti. 2009. Use of algae and aquatic macrophytes as feed in small scale aquaculture: A review, FAO Fisheries and Aquaculture Technical Paper, No. 531. IHP-UNESCO. 2011. Sediment deposition system on Saguling Reservoir, West Java. Final Report Year 2011. IHPUNESCO. Jakarta. 51 pp.

Kompas, 2011. Ukuran Ikan Bandeng Semarang Menyusut.

http://female.kompas.com/read/2010/06/08/ 16362831/.Ukuran.Bandeng.Semarang.Men yusut.

Krismono. 1992. Penelitian Potensi Sumberdaya Perairan Waduk Wadaslintang, Mrica, Karangates dan Waduk Selorejo untuk Budidaya Ikan dalam Keramba Jaring Apung. Buletin Penelitian Perikanan Darat. Vol. II No. 2 Juni. 20 hal.

Kusumastuti. 2009. Evaluasi lahan basah bervegetasi mangrove dalam mengurangi pencemaran lingkungan. Tesis. Universitas diponegoro: Semarang.

Landesman, L.; N.C. Parker; C.B. Fedler \& M. Konikoff. 2005. Modeling duckweed growth in wastewater treatment systems. Livestock Research for Rural Development, 17 (6): Art. \#61. Retrieved April 1, 2012, from http://www.lrrd.org/lrrd17/6/land17061.htm.

Leng, R.A.; J.H. Stambolie \& R. Bell. 1995. Duckweed - a potential high-protein feed resource for domestic animals and fish. Livestock Research for Rural Development,7(1): http://www.cipav.org.co/lrrd/lrrd7/1/3.htm.

Pancho, J.V. \& M. Soerjani. 1978. Aquatic weeds of Southeast Asia. Bogor: BIOTROP, SEAMEO, Regional Center for Tropical Biology 130 pp.

Rochdianto, A. 2004. Budidaya Ikan di Jaring Terapung. Penebar Swadaya. Jakarta. 89 hal.

Schröder, P.; J. Navarro-Aviñó; H. Azaizeh; A.G. Goldhirsh; S. DiGregorio; T. Komives; G. Langergraber; A. Lenz.; E. Maestri; A.R.Memon; A. Ranalli; L. Sebastiani; S. Smrcek; T. Vanek; S. Vuilleumier \& F. Wissing. 2007. Using phytoremediation 
technologies to upgrade waste water treatment in Europe. Environmental Science and Pollution Research, 14(7): 490-497.

Sukadi, M. F. 1991. Budidaya Ikan dalam Keramba Jaring Apung. Panduan Teknis. Puslitbang Perikanan. Jakarta. 36 hal.
Tavares, F.A.; J.B.R. Rodrigues; D.M. Fracalossi; J. Esquivel \& R. Roubach. 2008. Dried duckweed and commercial feed promote adequate growth performance of tilapia fingerlings. Biotemas, 21 (3): 91-97. 